periods between the large calvings is insignificant, except where ice streams run directly into the sea without forming ice shelves. The latter sections account for $2 \%$ of the coastline in question and a similar part is made up of ice rises. Thus, with the exception of these short segments, the ice front advances systematically over time intervals of a few decades. Large calvings interrupting the advance can be recognized by significant change in shape and position of the ice front.

A nearly continuous survey of the coastline from long. $9-44^{\circ} \mathrm{W}$. was carried out during January-February 1977 from the ship of the Norwegian Antarctic Research Expedition, 1976-77. The position of the ice front could be determined within $\pm 200 \mathrm{~m}$ by use of an integrated navigation system including a two-channel satellite receiver, in combination with a calibrated radar. Selected points along the coast were determined with a precision of $\pm \mathrm{ro} \mathrm{m}$, using both the shipborne navigation system and a separate, mobile, two-channel system.

A comparison of the repeated surveys of the position of the ice front reveal a pattern of high-velocity ice streams bounded by slow-moving ice, giving rise to complex strain fields. For example, the Filchner Ice Shelf shows northward movements increasing from nearly zero at long. $44^{\circ} \mathrm{W}$. (Gould Bay) to $2 \mathrm{~km}$ year ${ }^{-1}$ at long. $40^{\circ} \mathrm{W}$., over a distance of only $90 \mathrm{~km}$. At long. $40^{\circ} \mathrm{W}$. the ice front advanced $43 \mathrm{~km}$ between $195^{6}$ and 1977 , and during this period a $20 \mathrm{~km} \times 25 \mathrm{~km}$ piece of the ice shelf calved off between long. $42^{\circ} \mathrm{W}$. and $43^{\circ} \mathrm{W}$. East of $40^{\circ} \mathrm{W}$., toward Vahsel Bay, the velocities decrease to around $\mathrm{I} \mathrm{km} \mathrm{year-1.} \mathrm{Other}$ complicated patterns, with velocities exceeding $\mathrm{I} \mathrm{km}$ year ${ }^{-1}$ in the fastest sections, are found in several other places along the coast. The larger outflow rates are generally observed west of Kap Norvegia (long. $12^{\circ}$ W.) with a major exception at Jutultunga (long. ${ }^{\circ}$ W.), where the velocity exceeds $\mathrm{I} \mathrm{km}_{\text {year }}{ }^{-1}$ over a $60 \mathrm{~km}$ wide ice front. The velocity patterns reflect complicated ice dynamics related to the up-stream subglacial topography, and permit identification of zones of varying dynamic activity in the corresponding parts of the inland ice sheet.

Control on the early surveys is provided by those short coastal segments where ice shelf is absent, and generally the positions agree to within $\mathrm{I} \mathrm{km}$.

The calving is related to the strain patterns, and incipient break-off can be identified 20 years prior to final severing. This final calving is probably a rapid event, triggered by a storm, collision by a large iceberg, or large ocean swells.

The elevation of the ice front was measured at numerous locations by the 1976-77 expedition with a precision better than $\pm \mathrm{I} \mathrm{m}$. In general the elevations increase westwards from long. $9^{\circ} \mathrm{W}$. to $44^{\circ} \mathrm{W}$. Firn density at fixed depth also increases westwards, and consequently the mass of a unit width of the ice front is nearly doubled along this section. The mass outflow across separate coastline segments is calculated and related to the up-stream mass balance.

\title{
EVIDENGE AGAINST AND FACTORS PREVENTING MAJOR SURGES OF THE ANTARCTIC IGE SHEET
}

By G. DE Q. RoBin

(Scott Polar Research Institute, Lensfield Road, Cambridge CB2 IER, England)

Abstract. Although computer modelling using realistic flow parameters can simulate surging of the Antarctic ice sheet, the present model does not take into account certain factors that make surging less probable. Before discussing these factors, knowledge of the Antarctic ice sheet that might indicate the occurrence of former surging is reviewed. The following studies appear relevant: 
(a) Observed temperature-depth profiles approximate to steady-state solutions, whereas a major surge within the last io ooo to 20000 years would have produced markedly different temperature-depth profiles at Byrd and Vostok Stations.

(b) Isotopic profiles are estimated for steady-state and for surging behaviour of the Antarctic ice sheet. When these are compared with observed profiles no convincing evidence of surging over the past 10 ooo to 50 ooo years is seen.

(c) Studies of flow lines in and around the Ross Ice Shelf do not reveal any surging of discharge glaciers in the past I ooo to 2000 years.

(d) Although mass-balance calculations and balance-velocity calculations on the Antarctic ice sheet are not accurate, ice discharge is generally estimated to be within a factor of two of the total mass accumulation.

Three stabilizing factors that have not been included in computer models and need consideration are

(I) It appears unlikely that a surge will be propagated up-stream of any substantial bedrock slope that opposes the ice motion.

(2) The very high effective viscosity of great thicknesses of ice at very low temperatures adds considerable rigidity to the ice sheet at the lateral boundaries of any incipient surge.

(3) Strong convergence of flow lines towards ice streams and major trunk glaciers apparently provides a stabilizing factor.

\section{DISGUSSION}

T. J. Hughes: You claimed that the hardest part of an ice stream is the zone of converging flow at its head, and this hard ice would keep an ice stream surge from propagating inland. The zone of converging flow should be one of the softest parts of the ice stream, because strong lateral convergence deforms the whole bulk of ice, not just the basal and lateral shear zones. So bulk strain-softening should be a maximum, not a minimum, at the heads of ice streams and the surge could easily propagate inland.

On another point, in your surge paper with Weertman, was not the ablation zone at the glacier snout the means whereby you obtained compressive flow in the snout? If so, compressive flow in ice-stream tongues could be provided if the tongues were imbedded in confined and pinned ice shelves, and your surge mechanism might apply.

G. DE Q. RoBIn: I agree that your first point is of major importance, but you misinterpret my remarks. I was discussing the relative hardness of the lateral shear zone and the zone of converging flow. I believe the former is much softer than the latter, and hence cannot propagate inland as a single shear zone. I agree that the converging zone will be softer than the main ice sheet, but as to how much softer, we still need an answer. Certainly the important key to stability of ice streams lies in this zone, which needs further study.

As regards your second point, your argument does not apply, unless ice-stream discharge stops almost completely above the grounding line and then only if the equilibrium line is much higher.

C. Lorius: Your reconstruction of the D-Io profile for the elevation of origin of ice is very attractive. However at the $220 \mathrm{~m}$ depth there is a difference of about $\mathrm{I} .5 \mathrm{~km}$ with the elevations from the ice-core $\delta$ values. This difference decreases to zero in a rather rapid way, which may not be contradictory with the existence of surge.

RoвIN: I accept your point that surface lowering was quite rapid when ice from 220 to $200 \mathrm{~m}$ depth in the present core was being laid down, but any difference between us lies in our 
definition of a surge. I regard a surge as involving some dynamic instability leading to excessive surface lowering, followed by gradual recovery as the surface builds up to levels associated with the prevailing climate, rather than a relatively uniform, though considerable, change in surface level from that appropriate to one climatic regime to that associated with another.

W. F. Budd: Since the paper by Allison (1979) on the Lambert Glacier basin is not being presented I would like to comment that the interior of the Lambert basin appears to be one large region which has a quite definite positive balance. The region of Lambert Glacier which has apparently had substantial ice lowering of the order of $800 \mathrm{~m}$ or more seems to be rising at a high rate $(c .0 .2 \mathrm{~m} / \mathrm{a})$ which, if continued, would reach the previous thickness in the order of $4000 \mathrm{a}$.

My second point is that there seems to be a problem in matching the large, relatively rapid changes observed in isotope and gas-content profiles, without substantial increases in velocity, which are difficult to explain in terms of steady state or direct reaction to climate change.

\title{
REFERENCE
}

Allison, I. 1979. The mass budget of the Lambert Glacier drainage basin, Antarctica. Fournal of Glaciology, Vol. 22, No. 87 , p. $223-35$.

\section{MEGHANIGAL PROPERTIES OF ANTARGTIG DEEP-CORE ICE}

\author{
By H. ShojI and A. Higashi
}

(Department of Applied Physics, Faculty of Engineering, Hokkaido University, Sapporo, Japan o6o)

Abstract. Tensile tests were carried out with core-ice samples obtained from various depths at Byrd Station, Antarctica in 1968. Specimens for the tests were so prepared as to have their long axes parallel ( $\mathrm{L}$ specimen), perpendicular ( $\mathrm{T}$ specimen), and inclined at $45^{\circ}$ (I specimen) with respect to the axis of the core, or to the vertical direction of the ice sheet. Stress-strain relations for many specimens were obtained from tensile tests with different strain-rates and also at different temperatures between -10 and $-20^{\circ} \mathrm{C}$.

The stress-strain curves generally exhibited a type of stress saturation. This is different from that for either basal or non-basal glide of single crystals of ice, with which a large yield drop or strain-hardening effect were observed respectively. The saturated value of the stress on the curves was considered as the maximum stress or the yield value. The relationship between the strain-rate $\dot{\epsilon}$ and the maximum stress $\sigma$ was expressed as

$$
\dot{\epsilon}=A \sigma^{n} \text {. }
$$

This relationship can be drawn as a straight line with inclination $n$ on a $\log -\log$ plot and the softness or the degree of deformability is expressed by the value of $A$ or by the level of strainrate on the line at the same stress level. Although there was not much difference between $\mathrm{L}$ and $\mathrm{T}$ specimens as regards the softness for a sample from relatively shallow depth, which exhibited no strong preferred orientation of $c$-axes, there appear significant differences among $\mathrm{T}$ and $\mathrm{L}$ specimens with a sample of moderately oriented $c$-axes from deeper depth: the $\mathrm{L}$ specimens are easier to deform than the $\mathrm{T}$ specimens. And for samples of very strong preferred 